\title{
NEW QUASI-ATOMIC NANOSTRUCTURES CONTAINING EXCITON QUASIMOLECULES AND EXCITON QUASICRYSTALS: THEORY
}

\author{
S.I. Pokutnyi \\ Chuiko Institute of Surface Chemistry of National Academy of Sciences of Ukraine, \\ General Naumov Str., 17 Kyiv 03164, Ukraine, e-mail: pokutnyi.serg@gmail.com
}

In review, deals with the theory of exciton quasimolecules in a nanoheterostructures. It has been found that the formation of a exciton quasimolecule in a nanoheterostructures made up of aluminum oxide quantum dots synthesized in a dielectric matrix is of threshold character and can occur in a nanosystem where the distance D between the surfaces of quantum dots is given by the condition $D_{c}^{\{1\rangle} \leq D \leq D_{c}^{(2)}$. The existence of such distance $D_{c}^{(1)}$ arises from quantum size effects in which the decrease in the energies of interaction of the electrons and holes entering into the Hamiltonian of the "exciton molecule" with decrease of the distance D between the surfaces of the QD cannot compensate for the increase in the kinetic energy of the electrons and holes. At larger distances $D$ between the surfaces of quantum dots: $D \geq D_{c}^{(2)}$, the biexciton breaks down into two excitons (consisting of spatially separated electrons and holes), localized over QD surfaces.

It was shown that the convergence of two quantum dots up to a certain critical value $D_{c}^{(1)}$ between surfaces of quantum dot lead to overlapping of electron orbitals of superatoms and the emergence of exchange interactions. In this case the overlap integral of the electron wave functions takes a significant value. As a result, the conditions for the formation of quasimolecules from quantum dots can be created.

We have shown that in such a nanoheterostructures acting as "exciton molecules" (biexcitons consisting of spatially separated electrons and holes) are the quantum dots of aluminum oxide with excitons localizing over their surfaces. The position of the biexciton state energy band depends both on the mean radius of the quantum dots, and the distance between their surfaces, which enables one to purposefully control it by varying these parameters of the nanostructure.

As our variational calculations show, the interaction of the excitons with the surfaces of quantum dots ("intramolecular" interaction) is much stronger than that between quantum dots ("intermolecular" interaction). Due to the translational symmetry of such a nanoheterostructures of quantum dots, it permits propagation of electronic excitation in the form of biexcitons.

As follows form the results of the variational calculations, the major contribution to the biexciton binding energy is from the energy of exchange interaction of electrons and holes, which by far surpasses that from their Coulomb interaction.

It is established that at constant concentrations of biexcitons at temperatures $T$ below a certain critical temperature $T_{c}$ due to the radiative annihilation of one of the excitons forming a biexciton one can expect a new spectral band of luminescence shifted relative to the exciton band by the biexciton binding energy $E_{B}$. This new luminescence band disappears at temperatures above $T_{c}$. At a constant temperature $T<T_{c}$ the growth of exciton concentration brings about weakening of the exciton band and strengthening of the biexciton band of luminescence. 
Keywords: electrons, holes, biexciton ground singlet states, binding energy, Coulomb, polarization and exchange interaction, quantum dots, nanoheterostructures

\section{Introduction}

Recent advances of solid-state technology made it possible to produce a nanoheterostructures (NHS), where acting as lattice points are spherical dielectric or semiconductor quantum dots (QDs) with the mean radius $a=1-10 \mathrm{~nm}$ implanted in a transparent dielectric (or semiconductor) matrix [1]. Such sizes of QD are comparable with the de Broglie wavelength of the electron and hole or (and) with their Bohr radii. This leads to the spatial dimensional quantization of charge carriers playing a substantial part in optical and electrooptical processes in such nanosystems [1 - 24].

The studies of quasi 0 - D nanosystems made up of spherical QD with the mean radius in the range of 1 to $10 \mathrm{~nm}$ consisting of semiconductor (cadmium sulfide and selenide, gallium arsenide, zinc selenide) [1-3] and dielectric (aluminum oxide) [4 - 6] materials synthesized in dielectric (semiconductor) matrices attract considerable interest due to their unique photoluminescence properties, ability to effectively emit light in the visible and near infrared spectral range at room temperatures $[1-6]$. Optical and electro-optical properties of such quasi 0 -D nanosystems are to a large extent governed by the energy spectrum of the spatially confined electron-hole pair (exciton) [1 - 24].

During investigation of the optical characteristics of nanosystems with $\mathrm{CdS}, \mathrm{ZnSe}, \mathrm{Al}_{2} \mathrm{O}_{3}$ and Ge quantum dots in experimental papers [11 - 15] it was found that the electron can be localized above the surface of the QD while the hole here moves in the volume of the QD. In [25 -29] the appearance of superatoms located in dielectric matrices as cores containing $\mathrm{CdS}, \mathrm{ZnSe}$, $\mathrm{Al}_{2} \mathrm{O}_{3}$ and $\mathrm{Ge}$ quantum dots was apparently established experimentally for the first time. A substantial increase in the bond energy of the ground state of an electron in a superatom in comparison with the bond energy of an exciton in $\mathrm{CdS}, \mathrm{ZnSe}$ and $\mathrm{Al}_{2} \mathrm{O}_{3}$ and single crystals was detected in [8].

In [26 - 29] the optical characteristics of samples of borosilicate glasses doped with $\mathrm{CdS}$, $\mathrm{ZnSe}$ and $\mathrm{Al}_{2} \mathrm{O}_{3}$ at concentrations between $\mathrm{x} \approx 0.003 \%$ to $1 \%$ were investigated. The average radii в of $\mathrm{CdS}$ and $\mathrm{ZnSe} \mathrm{QDs}$ were in the range of $\varepsilon \approx 2.0-20 \mathrm{~nm}$. When there were large concentrations of $\mathrm{CdS}$ quantum dots in the samples (from $\mathrm{x} \approx 0.6 \%$ to $\mathrm{x} \approx 1 \%$ ) a maximum, interpreted by the appearance of bonded QD states, was detected in the low-temperature absorption spectra. In order to explain the optical characteristics of such nanosystems we proposed a model of a quasimolecule representing two ZnSe and CdS QDs that form an exciton quasimolecule as a result of the interaction of electrons and holes.

$t$ was noted $[25,27]$ that, at such a QD content in the samples, one must take into account the interaction between charge carriers localized above the QD surfaces. Therefore, in [10, 15], we develop the theory of a exciton quasimolecule (or biexciton) (formed from spatially separated electrons and holes) in a nanosystem that consists of ZnSe and CdS QDs synthesized in a borosilicate glassy matrix. Using the variational method, we obtain the total energy and the binding energy of the exciton quasimolecule (or biexciton) singlet ground state in such system as functions of the spacing between the QD surfaces and of the QD radius. We show that the biexciton formation is of the threshold character and possible in a nanosystem, in which the spacing between the QD surfaces exceeds a certain critical spacing. It is established that the spectral shift of the low-temperature luminescence peak [27] in such a nanosystem is due to quantum confinement of the energy of the biexciton ground state.

The convergence of two (or more) QDs up to a certain critical value Dc between surfaces of QD lead to overlapping of electron orbitals of superatoms and the emergence of exchange interactions [9]. In this case the overlap integral of the electron wave functions takes a significant value. As a result, the conditions for the formation of quasi-molecules from QDs can be created 
[10]. One can also assume that the above conditions of formation of quasimolecules can be provided by external physical fields. This assumption is evidenced by results of [30, 31], in which the occurrence of the effective interaction between QDs at considerable distances under conditions of electromagnetic field was observed experimentally. In [32] energies of the ground state of "vertical" and "horizontal" located pair of interacting QDs ("molecules" from two QDs) were determined as a function of the steepness of the confining potential and the magnetic field strength. The quantum part of nanocomputer, which was implemented on a pair of QDs ("molecules" from two QDs) with charge states is $n$ qubits [33]. The first smoothly working quantum computer has been on QDs with two electron orbital states as qubits, described by a pseudospin (S). As a single cell was taken a couple of asymmetric pair QDs with different sizes and significantly different own energy. The electron, injected into the heterostructure from the channel occupied the lower level. That is, it was located in a QD with larger size.

In the present review we show that the biexciton formation in a NHS made up of aluminum oxide quantum dots synthesized in a dielectric matrix is of threshold character and can occur in a nanosystem where the distance $D$ between the surfaces of QD is given by the condition

$D_{c}^{(1)} \subseteq D \subseteq D_{c}^{(2)}$. We also demonstrate that in such NHS acting as "exciton molecules" (or biexciton) are the quantum dots of aluminum oxide with excitons localizing over their surfaces. The position of the biexciton state energy band is shown to depend both on the mean radius of quantum dots, and the distance between their surfaces, which enables one to purposefully control it by varying these parameters of the NHS. It is established that at constant concentrations of biexcitons at temperatures $T$ below a certain critical temperature $T_{c}$ due to the radiative annihilation of one of the excitons forming a biexciton one can expect a new spectral band of luminescence shifted relative to the exciton band by the biexciton binding energy $E_{B}$. This new luminescence band disappears at temperatures above $T_{c}$. At a constant temperature $T<T_{c}$ the growth of exciton concentration brings about weakening of the exciton band and strengthening of the biexciton band of luminescence.

\section{Energy of the exciton quasimolecules ground singlet state formed from spatially separated electrons and holes}

Let us consider a model of a nanosystem composed of two dielectric (semiconductor) spherical quantum dots $\mathrm{QD}(\mathrm{A})$ and $\mathrm{QD}(\mathrm{B})$ of radius $a$ synthesized in a dielectric matrix with permittivity $\varepsilon_{1}$ ( $D$ is the distance between the spherical surfaces of QD). Quantum dots are of a dielectric (semiconductor) material with permittivity $\varepsilon_{\mathbf{z}}$. For simplicity and without loss of generality let us assume that holes $h(A)$ и $h(B)$ with effective masses $m_{n}$ are located at the centers of QD (A) and QD (B) while electrons $e(1)$ and $e(2)$ with effective masses $m_{\Theta}^{(1)}$ are localized near the spherical surfaces of QD (A) and QD (B), respectively ( ${ }^{n} a(1)-$ the distance from the electron $e(1)$ to the center of QD (A); ${ }^{r(2)}$ - the distance from the electron $e(2)$ to the

center of QD (B)) (Fig. 1). This assumption is justified by the fact that

$$
\left(\frac{\left.m_{f}^{j} 1\right)}{\hbar_{h}}\right) \ll 1
$$
also infer that an infinitely high potential barrier exists on the spherical interface between the QD and the matrix so that the electrons cannot get into the quantum dot while the holes cannot escape from it.

Let us now use this model to consider the possibility of the formation of an exciton from spatially separated electrons and holes (the holes are located at the centers of QD(A) and QD(B) and electrons are localized near their spherical surfaces). Using adiabatic approximation and the 
effective mass approximation, the Hamiltonian of the biexciton (of spatially separated electrons and holes) can be written in the form [15]:

$$
\widetilde{H}=\widetilde{H}_{A(1)}+\widetilde{H}_{B(2)}+\widehat{H}_{m t}
$$

where $\mathscr{H}_{B(1)}$ and $\tilde{H}_{B(2)}$ are the Hamiltonians of the excitons of spatially separated hole $h(A)$ and electron $e(1)$ and hole $h(B)$ and electron $e(2)$, respectively.

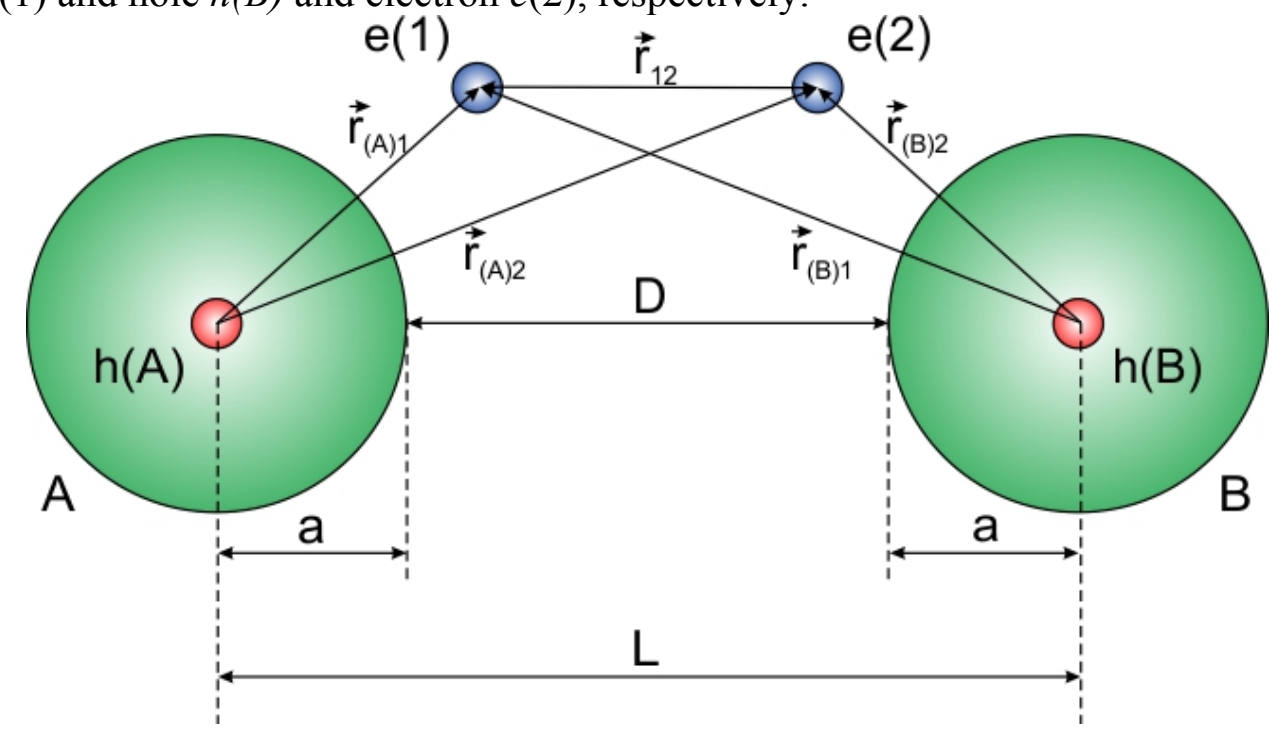

Fig.1. Schematic representation of a nanosystem consisting of two spherical QDs: QD(A) and $\mathrm{QD}(\mathrm{B})$ of radii $a$. The holes $h(A)$ и $h(B)$ are located at the centers of $\mathrm{QD}(\mathrm{A})$ and $\mathrm{QD}(\mathrm{B})$, and the electrons $e(1)$ and $e(2)$ are localized near the spherical surfaces of QD (A) and QD (B), ${ }^{r} A(1)$ - the distance from the electron $e(1)$ to the center of QD(A); - the distance from the electron $e(2)$ to the center of $\mathrm{QD}(\mathrm{A}) ;{ }^{r_{B(1)}}$ - the distance from the electron $e(1)$ to the center of $\mathrm{QD}(\mathrm{B}) ;{ }^{r_{B}(2)}$ - the distance from the electron $e(2)$ to the center of $\mathrm{QD}(\mathrm{B}) ; r_{1 z}$ - the distance between the electrons $e(1)$ and $e(2), L$ is the spacing between the QD centers, and $D$ is the spacing between the QD surfaces

The contribution of the energy of polarization interaction with the surface of QD to the Hamiltonians of the excitons $\vec{H}_{A(1)}$ and $\vec{H}_{B(2)}$ can be, as a first approximation neglected [20]. Thus the exciton Hamiltonian $\vec{H}_{A(1)}$ takes the form [15]:

$$
\tilde{H}_{A(1)}=-\frac{\hbar^{2}}{2 \mu t} \Delta_{(1)}+V_{\theta(1) h(A)}\left(r_{A(1)}, r_{h(A)}\right)+E_{\mathscr{Q}}
$$

where the first term is the exciton kinetic energy operator and the energy of Coulomb interaction $V_{\Theta(\mathfrak{m}(\mathrm{A})}$ between electron $e(1)$ and hole $h(A)$ is given be the following expression [7, 8]:

$$
V_{\theta(1)+(A)}=-\frac{1}{2}\left(\frac{1}{e_{1}}+\frac{1}{i_{\mathrm{a}}}\right) \frac{e^{2}}{r_{A(1)}}
$$

where $E_{g}$ is the bandgap energy of the dielectric (semiconductor) with permittivity $\varepsilon_{2}$. The Hamiltonian $\vec{H}_{B(2)}$ is of the same form as $\vec{H}_{A(1)}$ (2). In the first approximation we can neglect the contributions to the Hamiltonian $\vec{F}_{n t}$ of the interaction energies of the electrons $e(1)$ and 
$e(2)$ and the holes $\boldsymbol{h}(A)$ and $\boldsymbol{h}(B)$ with polarization fields induced by these charge carriers on the surfaces of QD (A) and QD (B) [20]. Thus the Hamiltonian $\widetilde{H}_{m t}$ incorporates only the energies of Coulomb interaction of electron $e(1)$ with hole $h(B)$, and electron $e(2)$ with hole $h(A)$, as well as that between electrons $e(1)$ and $e(2)$, and holes $h(A)$ and $h(B)$.

Under the assumption that the spins of the electrons $e(1)$ and $e(2)$ are antiparallel let us write down the normalized wave function of the ground singlet state of the biexciton as a symmetric linear combination of wave functions $\Psi_{1}\left(r_{A(1)}, r_{B(2)}\right)$ and $\psi_{2}\left(r_{A(2)}, r_{B(1)}\right)$ [15]:

$$
\psi_{S}\left(r_{A(12}, r_{A(2)}, r_{B(12,}, r_{B(2)}\right)=\left[2\left(1+S^{2}(D, a)\right)\right]^{-1 / 2}\left[\psi_{1}\left(r_{A(12}, r_{B(2)}\right)+\psi_{2}\left(r_{A(2)}, r_{B(12)}\right)\right]
$$

where $S(D, a)$ is the overlap integral of single-electron wave functions. Assuming that the electrons $e(1)$ and $e(2)$ move independently from each other, let us represent the wave functions $\Psi_{\Downarrow} 1\left(r_{\Downarrow} A(1), r_{B(a)}\right)$ and $\psi_{\downarrow} 2\left(r_{\Downarrow} A(2), r_{\downarrow} B(1)\right)$ (4) as a product of single-electron wave functions $\varphi_{A(1)}\left(r_{A(1)}\right)$ and $\varphi_{E(2)}\left(r_{B(2)}\right)$, as well as $\varphi_{A(2)}\left(r_{A(2)}\right)$ and $\varphi_{B(1)}\left(r_{B(1)}\right)$, respectively [15]. Let us also represent the single-electron wave functions as variational functions of Coulomb type [15]:

$$
\begin{aligned}
& \varphi_{A(1)}\left(r_{A(1)}\right)=A_{\exp }\left(-\bar{\mu}(a)\left(r_{A(1) / a_{\theta N 2}^{0}}\right)\right) . \\
& \varphi_{B(2)}\left(r_{B(2)}\right)=\tilde{A} \exp \left(-\bar{\mu}(\widetilde{a})\left(r_{B(2) / \alpha_{a x:}^{0}}\right)\right), \\
& \varphi_{B(1)}\left(r_{B(1)}\right)=A_{\exp }\left(-\bar{\mu}(a)\left(r_{B(1)}^{r} / \alpha_{\omega W}^{0}\right)\right) .
\end{aligned}
$$

where $\bar{\mu}(a)$ is a variational parameter,

$$
a_{* x}^{0}=\frac{2 \varepsilon_{1} \varepsilon_{2}}{\left(\varepsilon_{1}+\varepsilon_{2}\right)} \cdot \frac{\hbar^{2}}{k l_{0} e^{2}}
$$

is the Bohr radius of the 2D exciton localized over the flat interface between the semiconductor (dielectric) with permittivity $\varepsilon_{2}$ and the matrix with permittivity $\varepsilon_{1}$ (the hole is in the semiconductor and the electron is in the matrix, $e$ is the electron charge, $\mu_{0}=m_{\Theta}^{(1)} m_{h} /\left(m_{\theta}^{(1)}+m_{h}\right)$ is the reduced effective mass of the 2D exciton, $a-\left(t_{a_{6 x}}^{a}\right)$.

In the framework of the variational method, the energy of the biexciton ground singlet state, as a first approximation, is given by the mean value of the Hamiltonian $\vec{H}(1)$ over the states described by the wave functions of the 0th approximation $\Psi_{\mathrm{s}}(4)$ [15]:

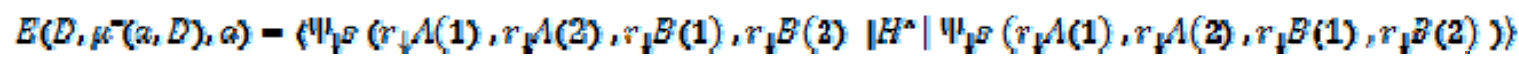

As follows from (6), the total energy $E_{0}(\mathbb{D}, \mathbb{Z})$ of the biexciton ground singlet state takes the form [15]:

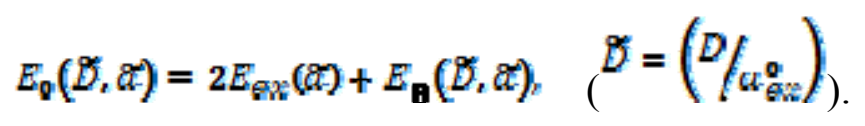


where $E_{\mathbf{B}}\left(\mathbb{D}, \mathbb{Z}^{2}\right)$ is the binding energy of the ground singlet state of the biexciton, and $E_{6 x}(\mathbb{R})$ is the binding energy of the ground state of the exciton (consisting of spatially separated electron and hole) localized over the surface of QD, which was worked out in $[7,8]$.

Fig. 2 presents the results of the variational calculations of the binding energy $E_{\mathbf{B}}(\mathbb{B}, \pi)$ studied in [4- 6] of the biexciton ground state in a nanosystem with QD of aluminum oxide of the mean radius $\bar{\alpha}_{1}=3.18 \mathrm{ng}$, (permittivity $s_{\mathbf{z}}=10$, effective mass of the hole in QD $\left(m_{h} / m_{\mathrm{v}}\right.$ $=6.2$ ), synthesized in a dielectric matrix of the vacuum oil VM-4 (permittivity $\varepsilon_{1}=1.96$, the effective mass of the electron in the matrix was deduced in [21] and amounts to 0,537 , the Bohr radius (5a) of the 2D exciton $a_{G x}^{\%}=0.35 \mathrm{~nm}$ ). Authors of [4- 6] studied nanostructures doped with $x=0.003 \%$ to $1 \%$ concentrations of aluminum oxide. At concentrations of QD higher than $x \cong 0.6 \%$ one needs to take into account the interactions of the charges localized over the surfaces of quantum dots. The variational method that we used for the calculation of the biexciton ground state binding energy $E_{\mathbf{n}}\left(D^{\circ}, a\right)$ is applicable provided that it is much smaller than the binding energy of the exciton ground state $E_{e x}(2)$, i.e. the following condition must be fulfilled:

$$
\left(E_{3}(\mathbb{Q}, a) / E_{\exp }(a)\right) \ll 1
$$

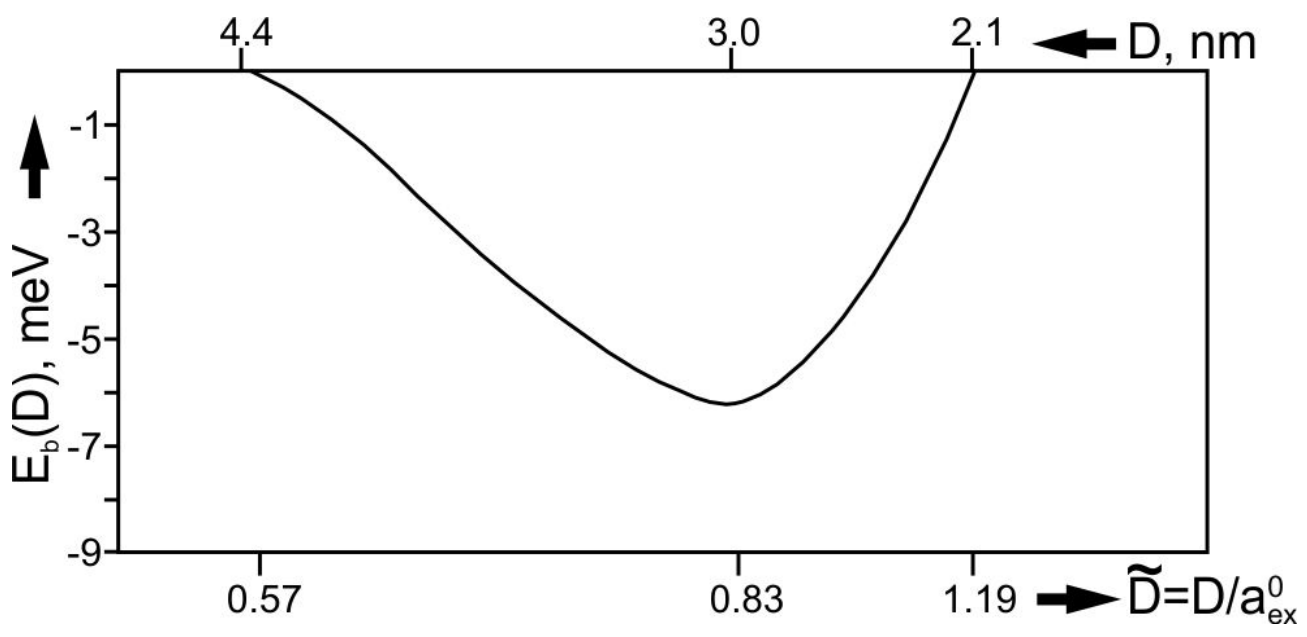

Fig. 2. The dependence of the binding energy of the ground singlet state $E_{\mathbf{B}}\left(\mathbb{D}, \bar{a}_{1}\right)$ of the biexciton (consisting of spatially separated electrons and holes) in a nanosystem made up of two spherical aluminum oxide quantum dots $\mathrm{QD}(\mathrm{A})$ and $\mathrm{QD}(\mathrm{B})$ with the mean radius $\pi_{1}=3.18 \mathrm{~nm}$, on the distance $D$ between the surfaces of $\mathrm{QD}(\mathrm{A})$ and $\mathrm{QD}(\mathrm{B})$. Here $a_{0 x}^{0}=0.35 \mathrm{~nm}$ is the Bohr radius of the two-dimensional exciton (consisting of spatially separated electron and hole).

The binding energy $E_{\mathbf{B}}(\boldsymbol{B}, a)$ of the biexciton ground state in a nanosystem with QD of aluminum oxide of the mean radius $\bar{a}_{\mathbf{1}}=3.18 \mathrm{~nm}$ has a minimum $E_{B}^{(1)}\left(D_{1}, \bar{a}\right) \approx-7,03 \mathrm{meV}$ (at the distance $\left.n_{1} \propto 2.93 \mathrm{~nm}\right)$ (Fig. 2) ( $D / a_{\mathrm{ex}}^{0}$ corresponds to the critical temperature $\left.T_{\mathbf{c}} \approx 81.6 K\right)$. As it follows form Fig.1, biexciton appears in the nanosystem at distances $D \approx D_{c}^{(1)} \cong 2.1 \mathrm{~nm}$ between the surfaces of QD. The formation of such a biexciton (,exciton molecule") is of threshold character and can occur in a nanosystem with quantum dots of the mean radius $\overline{\boldsymbol{a}}_{1}$, where the distance $D$ between the surfaces of QD exceeds a certain critical 
value $D_{c}^{(1)}$. The existence of such distance $D_{c}^{(1)}$ arises from quantum size effects in which the decrease in the energies of interaction of the electrons and holes entering into the Hamiltonian (Eq. (1)) of the "exciton molecule" with decrease of the distance $D$ between the surfaces of the QD cannot compensate for the increase in the kinetic energy of the electrons and holes.

The binding energy of the exciton $E_{6 x}(a)$ amounts to $E_{\text {ex }}\left(\bar{a}_{1}\right) \cong-100,8 \mathrm{meV}[7,8]$, with the energy of the biexciton ground state $(7)$ taking the value $E_{0}\left(\tilde{D}_{1}, \bar{a}\right) \approx-208,6 \mathrm{meV}$. It should be emphasized that the criterion (8) of the applicability of the variational method for the calculation of the biexciton binding energy $E_{\mathbf{6}}(\mathbb{D}, \boldsymbol{a})$ is fulfilled $\left(E^{(1)}\left(D_{1}, \bar{a}_{1}\right) / E_{e x}\left(\bar{a}_{1}\right)\right) \simeq 0.07$. At larger distances $D$ between the surfaces of QD: $D \supseteq D_{c}^{(D)} \cong 4.4 \mathbf{n m}$, the biexciton breaks down into two excitons (consisting of spatially separated electrons and holes), localized over QD surfaces (Fig.1). Thus a biexciton can be formed in a nanosystem where $D_{c}^{(1)} \subseteq D \leq D_{c}^{(2)}$. Furthermore, a biexciton can exist only at temperatures lower than the critical temperature $T_{C}=81.6 \mathrm{~K}$. In the aluminum oxide monocrystal with the binding energy $E_{B}=0.61 \mathrm{meV}$ (which corresponds to the temperature 7.04 K) the biexciton binding energy $E_{B}^{(1)}$ is almost 12 times as large.

As follows form the results of the variational calculations, the major contribution to the biexciton binding energy is from the energy of exchange interaction of electrons and holes, which by far surpasses that from their Coulomb interaction (i.e. the ratio $\leq 0.11$ ). Since the calculations of the biexciton ground state binding energy $\mid E_{\mathbf{z}}(\mathbb{B}, \mathbb{Z}) \|$ in the nanosystem are variational, the values of $\left|E_{\mathbf{a}}(\tilde{D} . \tilde{E})\right| \mid$ can be somewhat underestimated.

\section{Biexciton in quasicrystal}

In a NHS (mean radius of QD $\bar{a}_{\mathbf{1}}=3.18 \mathrm{~nm}$, and the distance between the surfaces of aluminum oxide QD $D_{1}=2.93 \mathrm{~nm}$ ) at temperatures below the critical value $T_{c}=81.6 \mathrm{~K}$ (which corresponds to the biexciton binding energy $E_{B}=7.03 \mathrm{meV}$ ) an "exciton molecule" can be formed (biexciton consisting of spatially separated electrons and holes). Acting as "exciton molecules" in such a NHS are the quantum dots of aluminum oxide, with excitons (consisting of spatially separated electrons and holes) localized over their surfaces. As our variational calculations show, the interaction of the excitons with the surfaces of QD ("intramolecular" interaction) is much stronger than that between quantum dots ("intermolecular" interaction). Due to the translational symmetry of such a NHS of QD, it permits propagation of electronic excitation in the form of biexcitons.

The energy level of the biexciton $E_{0}\left(B_{1}, \bar{a}_{1}\right)(7)$ turns, in this case, into a biexciton energy band with the width $\Delta E_{0}(D, a) \approx\left(\hbar^{2} / 2 M_{\Theta x} D_{1}^{2}\right)$ (where $M_{\Theta x}=\left(m_{h}+m_{\Theta}^{(1)}\right.$ ) is the translational mass of the exciton of spatially separated electron and hole). Quantitative assessment of the width of the biexciton band yields the value of about $3 \mathrm{meV}$ (which corresponds to the temperature of $35 \mathrm{~K}$ ). In such a NHS the energy band of biexciton states is located below the bandgap of aluminum oxide NHS by $E_{0}\left(\tilde{D}_{1}, \bar{a}\right) \approx-208,6 \mathrm{meV}$. The position of this energy band is governed both by the mean radius $\bar{a}_{1}$ of QD, and the distance $D_{1}$ between QD surfaces. Thus by varying these parameters of the NHS, one can purposefully control the position of the energy band of biexciton states.

At higher temperatures $\left(T>T_{c}\right)$, a phase transition of the nanosystem can occur from the biexciton to exciton state. At a constant concentration of excitons (i.e. constant concentration of QD) and temperatures $T$ lower than $T_{c}$, one can expect a new luminescence band shifted from the 
exciton band by the value of the biexciton binding energy $E_{B}$. This new band disappears at higher temperatures $\left(T: T_{C}\right)$. At a constant temperature below critical $\left(T<T_{c}\right)$, an increase in exciton concentration (i.e. in QD concentration) brings about weakening of the exciton luminescence band and strengthening of the biexciton one.

\section{Conclusions}

Thus it has been shown that the exciton quasimolecule formation in a NHS made up of aluminum oxide quantum dots (QD) of the mean radius $\bar{\alpha}_{1}$ is of threshold character and can occur in a nanosystem where the distance $D$ between the surfaces of QD is given by the condition $D_{c}^{(1)} \subseteq D \subseteq D_{c}^{(2)}$. We have demonstrated that in such a NHS (with the mean radius $\bar{\alpha}_{1}=3.18 \mathrm{~nm}$ and the distance between surfaces of aluminum oxide QD $D_{1}=2.93 \mathrm{~nm}$ ) at temperatures lower than the critical temperature $T_{c}=81.6 \mathrm{~K}$ (which corresponds to the exciton quasimolecule binding energy $E_{B}=7.03 \mathrm{meV}$ ) an ,exciton molecule“ (a biexciton consisting of spatially separated electrons and holes) can be formed. Acting as "exciton molecules" in the NHS are aluminum oxide quantum dots with excitons (consisting of spatially separated electrons and holes) localizing over their surfaces. The interaction of the excitons with the QD surfaces ("intramolecular" interaction) is shown to be much stronger than that between quantum dots (,intermolecular" interaction).

We have also shown that the position of the biexciton band in the NHS depends both on the QD mean radius $\bar{\alpha}_{1}$ and the distance $D_{1}$ between QD surfaces. By varying these parameters, one can purposefully control the position of the energy band of biexciton states in the NHS. With increase in temperature above the threshold ( $T T_{L}$ ), a phase transition can occur from the biexciton to exciton state. It has been found that at a constant concentration of excitons (i.e. constant concentration of QD) and temperatures $T$ below $T_{c}$, one can expect a new luminescence band shifted from the exciton band by the value of the biexciton binding energy $E_{B}$. This new band disappears at higher temperatures $\left(T E T_{c}\right)$. At a constant temperature below $T_{c}$, an increase in exciton concentration (i.e. in QD concentration) brings about weakening of the exciton luminescence band and strengthening of the biexciton one.

Thus, NHS made up of "exciton molecules" are of considerable interest both physically and practically as novel nanomaterials for nano-optoelectronics [34-42].

\section{REFERENCES}

1. Alferov Zh. I. Nobel Lecture: The double heterostructure concept and its applications in physics, electronics, and technology. Rev. Modern Physics. 2001.73(3): 767.

2. Ekimov A., Hache F., Schanne-Klein M. Absorption and intensity-dependent photoluminescence measurements on CdSe quantum dots: assignment of the first electronic transitions: erratum. J. Opt. Soc. Amer., B. 1994. 11(3): 524.

3. Bondar N., Brodin M. Evolution of exciton states near the percolation threshold in two-phase systems with II-VI semiconductor quantum dots. Semiconductors. 2010.44 (7): 884.

4. Kulchin Yu. N., Shcherbakov A.V., Dzyuba V.P. Nonlinear-optical properties of heterogeneous liquid nanophase composites based on high-energy-gap A12O3 nanoparticles. Quantum Electr. 2008. 38 (2): 154.

5. Dzyuba V.P., Krasnok A.E., Kulchin Yu.N. Nonlinear refractive index of dielectric nanocomposites in weak optical fields. Techn. Phys. Lett. 2010.36 (11): 973.

6. Pokutnyi S.I. Excition states in semiconductor quantum dots in the modified effective mass approximation. Semiconductors. 2007. 41 (11): 1323.

7. Pokutnyi S.I. On an exciton with a spatially separated electron and hole in quasi-zerodimensional semiconductor nanosystems. Semiconductors. 2013.47 (6): 791. 
8. Pokutnyi S.I. Binding energy of the exciton of a spatially separated electron and hole in quasizero-dimensional semiconductor nanosystems. Technical Physics Letters. 2013. 39(3): 233.

9. Pokutnyi S.I., Kulchin Yu. N., Dzyuba V.P. Binding energy of excitons formed from spatially separated electrons and holes in insulating quantum dots. Semiconductors. 2015. 49(10): 1311.

10. Pokutnyi S.I. Excitons based on spatially separated electrons and holes in $\mathrm{Ge} / \mathrm{Si}$ heterostructures with germanium quantum dots. Low Temperature Physics. 2016. 42(12): 1151.

11. Pokutnyi S.I. Optical absorption by colloid quantum dots CdSe in the dielectric matrix. Low Temperature Physics. 2017. 43(12): 1797.

12. Pokutnyi S.I. Optical spectroscopy of excitons with spatially separated electrons and holes in nanosystems containing dielectric quantum dots. J. Nanophoton. 2018. 12(2): 026013.

13. Pokutnyi S.I. Exciton spectroscopy with spatially separated electron and hole in $\mathrm{Ge} / \mathrm{Si}$ heterostructure with germanium quantum dots. Low Temperature Physics. 2018. 44(8): 819.

14. Pokutnyi S.I. Exciton spectroscopy of spatially separated electrons and holes in the dielectric quantum dots. Crystals. 2018. 8(4): 148.

15. Pokutnyi S.I. Biexcitons formed from spatially separated electrons and holes in quasi-zerodimensional semiconductor nanosystems. Semiconductors. 2013. 47(12): 1626.

16. [10] Pokutnyi S.I., Kulchin Yu. N., Dzyuba V.P. Biexciton in nanoheterostructures of dielectric quantum dots. J. Nanophoton. 2016. 10: 036008.

17. Pokutnyi S.I., Kulchin Yu. N. Special Section Guest Editorial: Optics, Spectroscopy and Nanophotonics of Quantum Dots. J. Nanophoton. 2016. 10(3): 033501.

18. Pokutnyi S.I. Biexciton in quantum dots of cadmium sulfide in a dielectric matrix. Technical Physics. 2016. 61(11): 1737.

19. Pokutnyi S.I. Excitonic quasimolecules in nanosystems of semiconductor and dielectric quantum dots. Modern Chemistry Applications. 2016. 4(4): 188.

20. Pokutnyi S.I. Excitonic quasimolecules in nanosystems of quantum dots. Optical Engineering. 2017. 56(9): 091603.

21. Pokutnyi S.I. Biexciton in nanoheterostructures of germanium quantum dots. Optical Engineering. 2017. 56 (6): 067104.

22. S.I. Pokutnyi. Excitonic quasimolecules formed by spatially separated electrons and holes in a Ge/Si heterostructure with germanium quantum dots. J. Appl. Spectroscopy. 2017. 84(2): 268.

23. Pokutnyi S.I., Kulchin Yu. N., Dzyuba V.P. Biexciton states in nanoheterostructures of dielectric quantum dots. J. Physics Conference Series. 2018. 1092 (1): 12029.

24. Pokutnyi S.I. Exciton quasimolecules formed from spatially separated electrons and holes in nanostructures with quantum dots of germanium. Molecular Crystals and Liquid Crystals. 2018. 674(1): 92.

25. Yakimov A.I., Dvurechensky A.V. Effects of electron-electron interaction in the optical properties of dense arrays of quantum dots Ge/Si. JETP. 2001. 119: 574.

26. Grabovskis V., Dzenis Y., Ekimov A. Photoionization of semiconductor microcrystals in glass. Sov. Phys. Solid State. 1989. 31(1): 272.

27. Bondar N. Photoluminescence quantum and surface states of excitons in $\mathrm{ZnSe}$ and $\mathrm{CdS}$ nanoclusters. J. Luminescence. 2010. 130(1): 1.

28. Ovchinnikov O.V., Smirnov M.S., Shatskikh T.S. Spectroscopic investigation of colloidal CdS quantum dots - methylene blue hybrid associates. J. Nanopart. Res. 2014. 16: 2286.

29. Dzyuba V.P., Kulchin Yu. N., Milichko V.A. Quantum size states of a particle inside the nanopheres. Advanced Material Research A, 2013. 677: 42.

30. Lalumiure K., Sanders B., Van Loo F. Imput - output theory for waveguide QED with an ensemble of inhomogeneous atoms. Phys. Rev. A. 2013. 88: 43806.

31. Van Loo F, Fedorov A, Lalumiure K. Photon-mediated interactions between distant artificial atoms. Science, 2013. 342: 1494. 
32. Lozovik Y.E. Electronic and collective properties of topological insulators. Advanc. Phys. Scienc. 2014. 57: 653.

33. Valiev K. Quantum computers and quantum computing. Advanc. Phys. Sc., 2005. 48 : 1.

34. Pokutnyi S.I. Optical nanolaser on the heavy hole transition in semiconductor nanocrystals: Theory. Phys. Letter. A. 2005.342 (4): 347.

35. Pokutnyi S.I. Stark effect in semiconductor quantum dots. J. Applied Physics. 2004. 96: 100015.

36. Pokutnyi S.I., Ovchinnikov O.V., Smirnov M.S. Sensitization of photoprocesses in colloidal $\mathrm{Ag}^{2} \mathrm{~S}$ quantum dots by dye molecules. J. Nanophoton. 2016. 10: 033505.

37. Pokutnyi S.I., Ovchinnikov O.V. Relationship between structural and optical properties in colloidal CdxZn1-xS quantum dots in gelatin. J. Nanophoton. 2016. 10: 033507.

38. Pokutnyi S.I., Ovchinnikov O.V. Absorption of light by colloidal semiconducor quantum dots. J. Nanophoton. 2016. 10: 033506.

39. Pokutnyi S.I. Strongly absorbing light nanostructures containing metal quantum dots. $J$. Nanophoton. 2018. 12 (1): 012506.

40. Pokutnyi S.I., Kulchin Yu.N., Amosov A.V., Dzyuba V.P. Optical absorption by a nanosystem with dielectric quantum dots. Proc. SPIE. 2019. 11024: 1102404.

41. Pokutnyi S.I. Exciton states formed by spatially separated electron and hole in semiconductor quantum dots. Technical Physics. 2015. 60: 1615.

42. Pokutnyi S.I. Spectroscopy of quasiatomic nanostructures. J. Optical Technol. 2015. 82: 280.

\section{НОВЫЕ КВАЗИАТОМНЫЕ НАНОСТРУКТУРЫ, СОДЕРЖАЩИЕ ЭКСИТОННЫЕ КВАЗИМОЛЕКУЛЫ И ЭКСИТОННЫЕ КВАЗИКРИСТАЛЛЫ: ТЕОРИЯ}

\section{С.И. Покутний}

Институт химии поверхности им. А.А. Чуйко Национальной академии наук Украинь, ул. Генерала Наумова, 17, Киев, 03164, Украина, e-mail: pokutnyi.serg@gmail.com

В обзоре развивается теория экситонных квазимолекул в наногетероструктурах. Установлено, что образование экситонной квазимолекуль в наногетероструктурах, содержащче квантовые точки оксида алюминия, синтезированные в диэлектрической матрице, носит пороговый характер и может происходить в наносистеме, где расстояние $D$ между поверхностями квантовых точек определяется условием $D_{c}^{(1)} \subseteq D \subseteq D_{c}^{(2)}$. Существование такого расстояния $D_{c}^{(1)}$ обусловлено квантовыми размерными эффектами, в которых уменьшение энергий взаимодействия электронов $и$ дырок, входящих в гамильтониан «молекуль экситона», с уменьшением расстояния D между поверхностями КТ не может компенсировать увеличение кинетической энергии электронов и дырок. На больших расстояниях D между поверхностями квантовых точек, таких что $D \geq D_{c}^{(2)}$, биэкситон распадается на два экситона (состоящих из пространственно разделенных электронов и дырок), локализованных над поверхностями КT.

Установлено, что сходимость двух квантовых точек до некоторого критического значения $D_{c}^{(1)}$ между поверхностями квантовой точки приводит $\kappa$ перекрытию электронных орбиталей суператомов и возникновению обменных взаимодействий. В этом случае интеграл перекрытия волновых функиий электрона принимает 
существенное значение. В результате могут быть созданы условия для формирования квазимолекул из квантовых точек.

Как показывают вариационные расчеты, взаимодействие экситонов $c$ поверхностями квантовых точек («внутримолекулярное» взаимодействие) значительно сильнее, чем между квантовыми точками («межмолекулярное» взаимодействие). Благодаря трансляционной симметрии таких наногетероструктур из квантовых точек, между поверхностями квантовых точек движется электронное возбуждение в виде биэкситона.

Как следует из результатов вариационных расчетов, основной вклад в энергию связи биэкситонов вносит энергия обменного взаимодействия электронов и дырок, которая намного превосходит энергию их кулоновского взаимодействия.

Показано, что такие наногетероструктуры состоят из «экситонных молекул» (биэкситонов из пространственно разделенных электронов и дырок). Установлено, что положение энергетической зоны биэкситонных состояний зависит как от среднего радиуса квантовых точек, так и от расстояния между поверхностями квантовых точек. Последнее обстоятельство позволяет целенаправленно управлять положениями энергетической зоны биэкситонных состояний, изменяя эти параметры наноструктуры.

Показано, что при постоянных концентращиях биэкситонов при температурах ниже определенной критической температуры $T_{c}$ вследствие излучательной аннигиляции одного из экситонов, образующих биэкситон, можно ожидать новую спектральную полосу излучательния, смещуенную относительно экситонной полосы на энергию связи биэкситонов $E_{B}$. Эта новая полоса излучательния исчезает при температурах выше $T_{c .}$ При постоянной температуре $T<T_{c}$ рост концентрации экситонов приводит $\kappa$ ослаблению экситонной полосы и усилению биэкситонной полосы люминесценции.

Ключевые слова: электроны, дырки, основное синглетное состояние биэкситонов, энергия связи, кулоновское, поляризачионное и обменное взаимодействие, квантовые точки, наногетероструктуры

\section{НОВІ КВАЗІАТОМНІ НАНОСТРУКТУРИ, ЩО МІСТЯТЬ ЕКСИТОННІ КВАЗІМОЛЕКУЛИ І ЕКСИТОННІ КВАЗІКРИСТАЛИ: ТЕОРІЯ}

\section{C.I. Покутній}

Інститут хімії поверхні ім. О.О. Чуйка Начіональної академії наук України, вул. Генерала Наумова, 17, Київ, 03164, Украӥна, e-mail: pokutnyi.serg@gmail.com

У огляді розвивається теорія екситонних квазімолекул в наногетероструктурах. Встановлено, щзо утворення екситонної квазімолекул в наногетероструктурах, щзо містять квантові точки оксиду алюмінію, синтезовані в діелектричній матриці, носить пороговий характер і може відбуватися в наносистемах, в яких відстань $D$ між поверхнями квантових точок визначається умовою $D_{c}^{(1)} \leq D \leq D_{c}^{(2)}$. Існування такої відстані $D_{\varepsilon}^{(1)}$ обумовлено квантовими розмірними ефектами, в яких зменшення енергій взаємодіі електронів $i$ дірок, що входять в гамільтоніан «молекули екситона», зі зменшенням відстані $D$ між поверхнями KT не може компенсувати збільшення кінетичної енергії електронів і дірок. На великих відстанях D між поверхнями квантових 
точок, таких щчо $D \geq D_{c}^{(2)}$, біекситон розпадається на два екситона (щуо складаються 3 просторово розділених електронів та дірок), локалізованих над поверхнями КТ. Установлено, щзо зближення двох квантових точок до деякого критичного значення $D_{c}^{(1)}$ між поверхнями квантової точки призводить до перекриття електронних орбіталей суператомів $і$ виникнення обмінних взаємодій. У изьому випадку інтеграл перекриття хвильових функиій електрона приймає суттєве значення. В результаті можуть бути створені умови для формування квазімолекул з квантових точок.

Як показують наші варіаційні розрахунки, взаємодія екситонів з поверхнями квантових точок («внутрішньомолекулярна» взаємодія) значно сильніша, ніж між квантовими точками ( «межмолекулярна» взаємодія). Завдяки трансляційної симетрії таких наногетероструктур з квантових точок, між поверхнями квантових точок рухається електронне збудження у вигляді біекситона.

Як випливає з результатів варіаційних розрахунків, основний внесок в енергію зв'язку біекситона вносить енергія обмінної взаємодї електронів і дірок, яка набагато перевершує енергію їх кулонівської взаємодії.

Показано, щуо такі наногетероструктури складаються з «екситонних молекул» (біекситона з просторово розділеними електронами та дірками). Встановлено, щзо положення енергетичної зони біекситонних станів залежить як від середнього радіуса квантових точок, так $i$ від відстані між поверхнями квантових точок. Остання обставина дозволяе цілеспрямовано управляти положеннями енергетичної зони біекситонних станів, змінюючи циі параметри наноструктури.

Показано, щуо при постійних концентраціях біекситона при температурах нижче певної критичної температури $T_{c}$ внаслідок випромінювальної анігілящії одного $з$ екситонів, що утворюють біекситона, можна очікувати нову спектральну смугу випромінювання, зміщену щзодо екситонної смуги на енергію зв'язку біекситона $E_{B}$. Ця нова смуга випромінювання зникає при температурах вище $T_{c}$. При постійній температурі $T<T_{c}$ зростання концентрації екситонів призводить до ослаблення екситонної смуги і посилення біекситона смуги люмінесценції.

Ключові слова: електрони, дірки, основний синглетний стан біекситона, енергія зв'язку, кулонівська, поляризаційна і обмінна взаємодія, квантові точки, наногетероструктури 